\title{
PIIISGUC.ORG
}

"iş, GÜÇ" ENDÜSTRI iLişKILERI VE INSAN KAYNAKLARI DERGISi

"IS, GUC" INDUSTRIAL RELATIONS AND HUMAN RESOURCES JOURNAL

\section{Çalışma Yaşamının Esnekleştirilmesinde Bir Araç Olarak Toplu Pazarlık ve Cam Grup Sözleşmesi Deneyimi (2003-2012)}

\author{
Can ŞAFAK
}

Kristal-İş Sendikası

Ocak/January 2014, Cilt/Vol: 16, Sayı/Num: 1, Page: 83-100

ISSN: 1303-2860, DOI: 10.4026/1303-2860.2014.0245.x

Makalenin on-line kopyasına erişmek için / To reach the on-line copy of article: http://www.isguc.org/?p=article\&id=540\&cilt=16\&sayi=1\&yil=2014

Makale İçin İletişim/Correspondence to:

Can ŞAFAK / Email: cansafak@gmail.com 


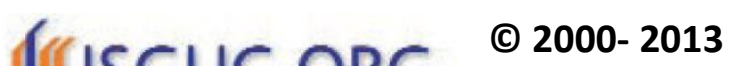 \\ "İş,Güç" Endüstri ilişkileri ve İnsan Kaynakları Dergisi "Işs,Güç" Industrial Relations and Human Resources Journal
}

\author{
Ocak/January 2014, Cilt/Vol: 16, Say1/Num: 1, \\ Sayfa/Page: 83-100, DOI: 10.4026/1303-2860.2014.0245.x
}

"İş,Güç" Endüstri İlişkileri ve İnsan Kaynakları Dergisi, yılda dört kez yayınlanan hakemli, bilimsel elektronik dergidir. Çalışma hayatına ilişkin makalelere yer verilen derginin temel amact; belirlenen alanda akademik gelişime ve paylaşıma katkıda bulunmaktır.

"İş,Güç" Endüstri İlişkileri ve İnsan Kaynakları Dergisi'nde, 'Türkçe' ve 'İngilizce' olarak iki dilde makale yayınlanmaktadır. "İş,Güç" Endüstri İlişkileri ve İnsan Kaynakları Dergisi, ulusal ve uluslararası birçok indekste taranmaktadır. (Cabell's Directories, Ebsco Socindex, Index Islamicus, Index Copernicus International, Worldwide Political Science Abstracts, Sociological Abstract, Ulakbim Sosyal Bilimler Veritabanı, ASOS Index)

Editörler Kurulu / Editorial Board Aşkın Keser (Uludă̆ University) K.Ahmet Sevimli (Uludăg University) Şenol Baştürk (Uludağ University)

\section{Editör / Editor in Chief}

Şenol Baştürk (Uludăg University)

\section{Uygulama / Design}

Yusuf Budak (Kocaeli University)

Tarandığı Indeksler / Indexes ASOS INDEX

CABELL'S DIRECTORIES EBSCO SOCINDEX Index ISLAMICUS Index COPERNICUS Int. Sociological Abstract ULAKBİM Sosyal Bilimler Veritanı

Worldwide Political Science Abstracts

\author{
Yayın Kurulu / Editorial Board \\ Dr.Şenol Baştürk (Uludă̆ University) \\ Yrd.Doç.Dr.Zerrin Fırat (Uludă̆ University) \\ Doç.Dr.Aşkın Keser (Uludă̆ University) \\ Prof.Dr.Ahmet Selamoğlu (Kocaeli University) \\ Yrd.Doç.Dr.Ahmet Sevimli (Uludağ University) \\ Doç.Dr.Abdulkadir Şenkal (Kocaeli University) \\ Doç.Dr.Gözde Yılmaz (Marmara University) \\ Yrd.Doç.Dr.Memet Zencirkıran (Uludă̆ University)
}

Uluslararası Danışma Kurulu / International Advisory Board

Prof.Dr.Ronald Burke (York University - Kanada)

Assoc.Prof.Dr.Glenn Dawes (James Cook University - Avustralya)

Prof.Dr.Jan Dul (Erasmus University - Hollanda)

Prof.Dr.Alev Efendioğlu (University of San Francisco - ABD)

Prof.Dr.Adrian Furnham (University College London - Ingiltere)

Prof.Dr.Alan Geare (University of Otago - Yeni Zellanda)

Assoc. Prof. Dr. Diana Lipinskiene (Kaunos University - Litvanya)

Prof.Dr.George Manning (Northern Kentucky University - ABD)

Prof.Dr.Mustafa Özbilgin (Brunel University - UK)

Assoc. Prof. Owen Stanley (James Cook University - Avustralya)

Prof.Dr.Işık Urla Zeytinoğlu (McMaster University - Kanada)

Ulusal Danışma Kurulu / National Advisory Board

Prof.Dr.Yusuf Alper (Uludă̆ University)

Prof.Dr.Veysel Bozkurt (Ístanbul University)

Prof.Dr.Toker Dereli (Işık University)

Prof.Dr.Nihat Erdoğmuş (İstanbul Şehir University)

Prof.Dr.Ahmet Makal (Ankara University)

Prof.Dr.Süleyman Özdemir (İstanbul University)

Prof.Dr.Ahmet Selamoğlu (Kocaeli University)

Prof.Dr.Nadir Suğur (Anadolu University)

Prof.Dr.Nursel Telman (Maltepe University)

Prof.Dr.Cavide Uyargil (İstanbul University)

Prof.Dr.Engin Yildırım (Anayasa Mahkemesi)

Doç.Dr.Arzu Wasti (Sabancı University)

Dergide yayınlanan yazılardaki görüşler ve bu konudaki sorumluluk yazarlarına aittir.

Yayınlanan eserlerde yer alan tüm içerik kaynak gösterilmeden kullanılamaz.

All the opinions written in articles are under responsibilities of the authors.

The published contents in the articles cannot be used without being cited. 


\title{
Çalışma Yaşamının Esnekleştirilmesinde Bir Araç Olarak Toplu Pazarlık ve Cam Grup Sözleşmesi Deneyimi (2003-2012)
}

\author{
Can ŞAFAK
}

Kristal-İş Sendikası

\begin{abstract}
The year 2003 was an important turning point in labor law in Turkey. While the 'protection of the worker' was the underlying principle of labor law until then the new law was based on the principle of 'the protection of the business, 'i.e., that of capital. The new law intended to rid labor relations of rigidities and provide businesses with utmost flexibility in the organization of labor. It thus brought many forms of flexible labor practices under the rubric of the law. However, these changes in the labor law, bounded as they were by ILO and EU norms, were not found sufficient by business organizations. The new law legalized many forms of flexible labor while placing some restrictions on their practice, making them subject to certain rules, and in some cases such as length of work, to the consent of the worker. These types of restrictions led business organizations and employers' unions to seek to expand the bounds of flexible labor in the realm of collective bargaining, and the strategy had a considerable degree of success in the private sector. This study focuses on the glass industry where this strategy of business organizations has not been successful. Collective bargaining has been able to retain many of the old type restrictions on flexible labor in the glass industry, but some degree of flexibilization has been underway nevertheless. The study examines these changes and the transformation of the organization of labor and the structure of the workforce over a long period in the glass industry.
\end{abstract}

Keywords: Labor Law, Protection of the Worker, Flexible Labor Practices, ILO

Özet:

2003 yılı Türkiye'de iş hukuku alanında çok önemli bir dönüşüme sahne oldu. O zamana kadar iş hukukunun köklü ve evrensel temellerinden biri olarak bilinen "işçinin korunması" ilkesini esas alan iş yasası yürürlükten kaldırllarak, "işin korunması" ya da daha doğrudan bir anlatımla sermayenin korunması kaygısını merkezine alan yeni bir iş yasası kabul edildi. Yeni iş yasasının felsefesi, çalışma hayatını katı kurallardan arındırmak ve işin organizasyonunda işverene olabildiğince esneklik sağlayabilmekti. Ve yeni yasa pek çok esnek çalışma biçimine yer verdi, düzenledi. Ancak sinırları, Uluslararası Çalışma Örgütü (ILO) ve Avrupa Birliği (AB) normlarlyla çizilen bu değişim sermaye ve başta işveren sendikalarl olmak üzere sermaye örgütleri tarafindan yeterli bulunmadl. Yeni yasa esnekliğin önündeki engelleri kaldırıyor ancak bunun uygulanması bakımından kimi kurallar getiriyor ve özellikle çalışma sürelerinin esnekleştirilebilmesini işçinin onayına bağlıyordu. Bu sınırlamalar işveren sendikalarını yeni bir toplu pazarlık stratejisine yöneltti: iş yasasının düzenlediği esnek çalışma biçimlerini toplu iş sözleşmelerine aktarmak ve yeni düzenlemenin olanakl hale getirdiği esnekliği toplu pazarlık yoluyla genişletmek... Bu strateji özel sektörde önemli ölçüde başarılı oldu. Bu çalışma, işveren sendikalarının bu toplu pazarlık stratejisinin başarılı olamadı̆̆ bir sektörü, cam sektörünü konu alıyor. Esnek çalışma biçimlerini yasaklayan sert toplu sözleşme maddelerinin korunabildiği cam sektöründe, bu maddelere rağmen yaşanan esnekleşmeyi, işin organizasyonundaki ve işgücünün yapısındaki değişimi uzun sayılabilecek bir zaman aralı̆̆ içinde ortaya koymayı amaçlıyor.

Anahtar Kelimeler: İ̧̧ Kanunu, İş̧̧inin Korunması, Esnek Çalışma Biçimleri, ILO 


\section{Giriş}

2003 Haziran'ında 4857 sayılı yeni İş Kanunu'nun Resmi Gazete'de yayınlanarak yürürlüğe girmesiyle Türkiye'de, bireysel iş hukuku alanında önemli bir değişim/dönüşüm gerçekleştirildi: Esnekleşme! ${ }^{1}$ Bu esasta/ilkede bir değişimdi. $O$ tarihe kadar yürürlükte olan 1475 sayılı İş Kanunu'nun, iş hukukunun "işçinin korunması" ilkesini esas alan yaklaşımı yerini, yeni yasanın "işin/sermayenin korunması" ilkesini esas alan felsefesine bırakmıştı. Ve bu değişimle birlikte mevzuata yeni kavramlar girmişti: Denkleştirme çalışması ya da yoğunlaştırılmış iş haftası, telafi çalışması, ödünç işçilik, çağrı üzerine çalışma...

Sendikalar bütün bu süreç boyunca ve daha ilk andan başlayarak esnekliğe karşı çıktılar. Direnmeye çalıştılar. Ve sonra, fabrikalarda işin organizasyonunda esnekliğin zaten uzun yılardır ve son derece yaygın biçimde uygulanageldiğini fark ettiler.

Gerçekten de 2003 yılına geldiğimizde, iş mevzuatındaki bu önemli değişikliğin öncesinde de çalışma hayatında esneklik, hiç de yabancısı olmadığımız bir olguydu. Esnek çalışma başlığı altında ele alınan pek çok çalışma biçimi endüstride yıllardır uygulanmaktaydı. Vardiyalı çalışmalar, gece çalışmaları, geçici işçilik, taşeron işçiliği, fazla çalışmalar... Bütün bunlar esasen önceki mevzuatta da karşılığı olan esnek çalışma biçimleriydi. Ve mevzuatta bulunmayan ve hatta mevzuata aykırı bazı esnek çalışma biçimleri -burada telafi çalışmaları özellikle zikredilmelidir- 1475 sayılı İş Kanunu'nun "katı" düzenlemeleri yok sayılarak, başta metal ve dokumacilık olmak üzere kimi sektörlerde fiilen uygulanmaya başlanmıştı bile. Esneklik yeni İş Kanunu'nun hazırlık süreci içinde büyülü bir kelamdı sermaye için, değiştiren, çözen... Türkiye İşveren

\footnotetext{
14857 sayılı İş Kanunu 22.05.2003 günü kabul edilmiş ve 10.06.2003 gün ve 25134 sayılı Resmi Gazete'de yayımlanarak yürürlüğe girmiştir. Bu kanunla 25.8.1971 gününden beri uygulanmakta olan 1475 sayılı İş Kanunu, 14 üncü maddesi saklı tutularak yürürlükten kaldırılmıştır.
}

Sendikaları Konfederasyonu (TİSK) ve bağlı işveren sendikaları, bu yöndeki beklentilerini gerek bilim çevrelerinde ve gerekse parlamentoda, hükümet kanadında, bütün bu süreç boyunca etkili ve son derece sistemli biçimde gündemde tuttular. Ancak gene de Avrupa Birliği (AB) yönergeleri ve Uluslararası Çalışma Örgütü (ILO) normlarının bağlayıcılığı, 4857 sayılı İş Kanununun özellikle taşeron -alt işveren- ve belirli süreli iş sözleşmelerine ilişkin düzenlemelerini bir ölçüde de olsa sınırlayabildi. Bunun yanında "denkleştirme çalışması" başlığı altında düzenlenen "yoğunlaştırılmış iş haftası" uygulamaları "tarafların rızası" koşuluna bağlandı.

$\mathrm{Bu}$ yanlarıyla 4857 sayılı İş Kanunu işveren sendikalarını çok da hoşnut etmedi. Yeni düzenleme, esnek çalışma uygulamalarının önündeki katı engelleri kaldırmış da olsa işverene yeterli üstünlüğü tanımıyordu. Üstünlük toplu pazarlık yoluyla sağlanmalıydı! İşveren sendikalarının yeni yasanın yayımlanmasının hemen ardından ortaya çıkan, "toplu iş sözleşmelerinin 4857 sayılı İş Kanununa uyarlanması" adı altındaki ısrarlı çabaları, aslında Kanunun kendilerine tanımadığ1 üstünlüğü toplu sözleşme masalarında güç kullanarak sağlama manevrasıydı. $\mathrm{Bu}$ çerçevede işveren sendikalarının toplu pazarlık masalarındaki stratejisi, birbirine bağlı iki basamaktan/hedeften oluşuyordu.

1. 4857 sayılı Kanunla getirilen esnek çalışma modellerinin uygulanabilirliğinin önünde engel oluşturan "katı" toplu sözleşme hükümlerini ayıklamak. ${ }^{2}$

\footnotetext{
2 Aslında toplu iş sözleşmelerindeki bu "katı" düzenlemeler, işçi sendikalarının etkili bir mücadelesinin ürünü değildi. Bu düzenlemeler Türkiye'de, toplu iş sözleşmelerinin genel özelliklerinden biri olan yasa maddelerini sözleşme metinlerinde tekrarlamak alışkanlığıyla toplu sözleşmelere girmişlerdi. Ama şimdi, işveren sendikalarının toplu iş sözleşmelerine almakta ylllarca bir beis görmediği bu maddeler, esnekliğin önündeki son engeller haline gelmişlerdi.
} 
2. Atipik çalışma modellerini toplu iş sözleşmelerine aktarmak ve esnek çalışma modellerinin uygulanabilmesi için işverene tek yanlı üstünlük (inisiyatif) kazandiracak yeni düzenlemeler getirmek.

$\mathrm{Bu}$ çalışma, işverenlerin ve işveren sendikalarının çalışma hayatını esnekleştirme politikalarının toplu pazarlık sürecindeki uygulamalarını ve spesifik olarak da cam sektöründeki toplu pazarlık sürecini konu almaktadır. Sektörde 80 'lerin başlarından bu yana esnek istihdama yönelik gelişmeler ve atipik çalışma biçimlerinin toplu pazarlığa konu olması, bu alandaki sendika arayışı Kristal-İş Sendikası'nın arşiv belgelerine dayanılarak irdelenmiştir.

\section{Toplu pazarlık sürecinde genel görünüm}

\section{Kamuda esnekleşme hedefi ve toplu pazarlık}

Kamuda, 4857 sayılı İş Kanunu'nun yürürlüğe girmesinin ardından kamu işveren sendikalarının, çalışma sürelerinin esnekleştirilmesi ve atipik çalışma modellerinin toplu iş sözleşmelerine yansıtılması talebi, 2005 yılında 371 bin işçi için 138 işyeri ve işletmede örgütlü 23 sendikayla kamu işveren sendikaları arasında yürütülen toplu pazarlı̆̆ın başlıca uyuşmazlık konuları arasında yer almıştı. Ancak bu talepler, "gelirler politikası" çerçevesinde Hükümetle Türk-İş arasında tek elden yürütülen ücret pazarlığının gölgesinde kalmıştı. Zaten kamu işveren sendikalarının biraz da "dostlar alışverişte görsün" havasında ileri sürdükleri talepler çok da inandırıcı değildi. Nihayet, Hükümetle Türk-İş arasında 4 Temmuz 2005 günü imzalanan "çerçeve anlaşması" metninde, "işçi ve işveren sendikaları tarafından yeni getirilen teklifler toplu iş sözleşmelerinde yer almayacaktır ve müktesep haklar korunacaktır" hükmüne yer verilmişti. ${ }^{3}$ Sonraki dönemlerde "usulen" Türk-İş ilke kararlarında yer alsa da esnek çalışma tartışmaları kamuda, toplu pazarlığın gündemine pek girmedi. 2007'de 323 bin işçiyi kapsayan toplu pazarlık sürecini noktalayan çerçeve anlaşması 26 Haziran günü

32005 Yilı Kamu Toplu İş Sözleşmeleri Çerçeve Anlaşma Protokolü (04.07.2005). Bkz. www.turkis.org.tr imzalandığında, anlaşma metninde esnekliğe ilişkin herhangi bir ibare geçmiyordu. 2009'da, 7 Temmuz günü imzalanan çerçeve anlaşmasının kapsamındaki işçi sayısı 270 bindi ve bu anlaşma metninde de esnekliğe ilişkin herhangi bir ibare yoktu. 19 Temmuz günü imzalanan 2011 anlaşmasında da öyle, ancak toplu pazarlığın kapsamındaki işçi sayısı bu kez, 235 bin olarak açıklanıyordu. Çerçeve anlaşmaları, iyileştirme, ücret zamları, ücrete bağlı ödemeler, maktu ödemeler ve farkları ödenmesi başlıklarından oluşan metinlerdi artık. ${ }^{4}$ Ve 4857 sayılı yeni İş Kanunuyla getirilen esnek çalışma düzenlemeleri, kamuda toplu iş sözleşmelerine alınmadi.

Bunun kamuda önemli bir istisnası madenlerde ortaya çıktı. Kamu İşletmeleri İşverenleri Sendikası (Kamu-İş) ile Türkiye Maden İşçileri Sendikası arasında bağıtlanan Türkiye Kömür İşletmeleri Kurumu toplu iş sözleşmesinde, yoğunlaştırılmış iş haftası uygulamasına -işçiler arasında daha çok bilinen adıyla denkleştirme çalışmasına- izin verildi. ${ }^{5}$ Aynı düzenleme, taraflar arasında bağıtlanan ETİ Maden İşletmeleri Genel Müdürlüğü ve Elektrik Üretim Anonim Şirketi Genel Müdürlügü Afşin-Elbistan Linyitleri İşletme Müdürlüğü sözleşmelerine de alındı (m. 13 ve 16$){ }^{6}$

\footnotetext{
42007 Yılı Kamu Toplu İş Sözleşmeleri Çerçeve Anlaşma Protokolü (02.07.2007); 2009 Y Ylı Kamu Toplu İş Sözleşmeleri Çerçeve Anlaşma Protokolü (07.07.2009) ;2011 Yılı Kamu Toplu İş Sözleşmeleri Çerçeve Anlaşma Protokolü (19.07.2011). Bkz. www.turkis.org.tr

5 Buna göre işveren, "dört aylık süre içinde kalmak şartıyla, mevzuattaki çalışma sistemine uygun olarak haftalık normal çalışma süresini haftanın çalışılan günlerine farklı şekilde" dağıtabilmektedir (m. 15/b). Bkz. Kamu İşletmeleri İşverenleri Sendikası (Kamu-İş) ile Türkiye Maden İşçileri Sendikası arasında bağıtlanan Türkiye Kömür İşletmeleri Kurumu 13. Dönem işletme toplu iş sözleşmesi, 1.1.2011-31.12.2012.

${ }^{6}$ Bkz. ETİ Maden İşletmeleri Genel Müdürlüğü ve Elektrik Üretim Anonim Şirketi Genel Müdürlüğü Afşin-Elbistan Linyitleri İşletme Müdürlüğü Toplu İş Sözleşmesi, 1.1.2011-31.12.2012. Buna karşıllk Genel Maden-İş'in Kamu-İş ile bağıtladığı Türkiye Taşkömürü Kurumu (TTK) ve Maden Tetkik Arama (MTA) sözleşmelerinde yoğunlaştırılmış iş haftasına vurgu yapılmamakta, buna karşılık kamuda genel/ağırlıklı olarak görülen çalışma süresinin haftanın çalışılan günlerine eşit olarak dağıtılacağını emreden ya da çalışma saatlerini açık ve
} 
Yeni İş Kanununun esnekliği esas alan yaklaşımının kamuda toplu iş sözleşmelerine yansımamış olmasında, Türk-Işs'in kararlılığının değil hükümet kanadının bu noktada çok da israrlı olmamasının etkili olduğunu belirtmek gerekir. Hükümet için kamuda toplu pazarlık, esasen ücret ve gelirler politikası aracıydı ve asıl önemli olan da kısa/orta vadede gerçekleştirilecek özelleştirmelerdi. Ve zaman içinde özelleştirmeler birbiri ardınca gerçekleştirildi. Böylece kamuda tek yılarda bağıtlanan toplu sözleşmelerin kapsamındaki işçi sayısı 2005 ile 2011 yılları arasında 370 binden 235 bine geriledi.

Esnek çalışmaya ilişkin kavram ve düzenlemeler özelleştirilen kamu kuruluşlarının toplu sözleşmelerine de girmedi.

2006 yılında özelleştirilen Türk Hava Yolları (THY) sözleşmesi, tipik bir kamu sözleşmesiydi 4857 sayılı İş Kanunu ile getirilen esnek çalışma modellerine yer vermemekteydi ve çalışma süresinin haftanın çalışılan günlerine eşit olarak bölüneceği hüküm altına alınmıştı (m. 43, Eski md. 53). ${ }^{7}$ Sözleşmenin bu karakteri özelleştirme sonrasında da -özellikle işverenin denkleştirme çalışmalarını önleyen hükümleri sözleşmeden çıkarma çabalarına rağmenkorundu. 2008 yılında özelleştirilen Petkim'de, Petrol-İş̧in Kiplas'la bağıtladığı toplu iş sözleşmesinde, belirli süreli iş sözleşmesi ile işçi çalıştırılmasını sınırlayan düzenleme korunmuştur. ${ }^{8}$ Sözleşmede normal çalışma

kesin olarak belirleyen hükümler de yer almamaktadır. Bkz. Genel Maden-İş'in Kamu-İş, Türkiye Taşkömürü Kurumu (TTK) 24. Dönem Toplu İş Sözleşmesi, 1.1.201131.12.2012; Genel Maden-İș'in Kamu-İș, Maden Tetkik Arama (MTA) 14. Dönem Toplu İş Sözleşmesi, 1.1.201131.12.2012.

${ }^{7}$ Düzenleme aynen şöyledir: "İş süresi haftada en çok 45 saattir. Bu süre, haftada 6 işgünü çalışılan işyerlerinde günde 7,5 saati geçmemek üzere ve Cumartesi günleri kısmen veya tamamen tatil eden işyerlerinde haftanın çalışılan günlerine eşit ölçüde bölünerek uygulanır."

8 "Geçici duruşlarda veya niteliği bakımından geçici süreli sayılan işlerde üç aya kadar geçici işçi çalıştırılabilir. Bu çalışmalar 3 ayı geçtiği takdirde ve bu işçiler sendika üyesi olurlarsa Toplu İş Sözleşmesi hükümlerinden faydalanırlar." (m. 19) Petkim Petrokimya Holding A.Ş. Genel Müdürlüğü ve Bağlı İşyerleri İçin Türkiye Kimya, süreleri günde 8 , haftada 40 saat, üçlü vardiyada ise haftada 42 saat olarak kesin biçimde tespit edilmiştir (m. 33). ${ }^{9}$ Böylece Petkim'de yoğunlaştırılmış iş haftası uygulanabilmesi imkânını toplu pazarlık yoluyla ortadan kaldıran düzenleme özelleştirme sonrasında da korunmuştur. Fazla çalışma, ara dinlenmeleri, hafta tatili ve genel tatillerde çalışma, iş değişikliği gibi konularda da özelleştirme sonrasında bir esnekleşme

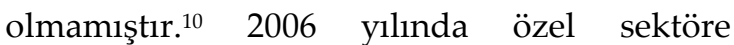
devredilen Tüpraş sözleşmesinde de paralel biçimde haftalık ve günlük çalışma sürelerini kesin biçimde tespit eden düzenlemeler korunmuş, yoğunlaştırılmış iş haftası uygulamasına imkân verilmemiştir. ${ }^{11}$

\section{Özel sektörde toplu sözleşmelerin esnekleştirilmesi}

Türkiye'de geleneksel olarak tekstil, deri, cam, çimento, seramik ve metal sektörlerinde işveren sendikalarıyla grup pazarlığı yürütülmektedir. Bunların yanında lastik sektöründe de işveren grubuyla tek elden yürütülen toplu sözleşmeler yapılmaktadır. Kamudaki ve özelleştirilen bu dev ölçekli işyerlerindeki durumun aksine, bir iki istisnayla özel sektörde bağıtlanan büyük ölçekli grup sözleşmelerinin 4857 sayılı İş Kanunu'nun esnek çalışmaya ilişkin hükümleriyle uyumu büyük ölçüde gerçekleştirilmiştir. ${ }^{12}$

Petrol, Lastik ve Plastik Sanayii İşverenleri Sendikası Kiplas ile Türkiye Petrol, Kimya, Lastik İşçileri Sendikası Petrol-İş Arasında İmzalanan Toplu İş Sözleşmesi 01.01.2011-31.12.2012.

9 Üç vardiya çalışmasında haftada 2 saat olan fazla çalışma karşılığ ücretlere ayda üç yevmiye ilave edileceği öngörülmektedir (m. 33).

${ }^{10}$ Krş. Petkim Petrokimya Holding A.Ş. Genel Müdürlüğü ve Bağlı İşyerleri İçin Kamu İşletmeleri İşverenleri Sendikası Kamu-İş ile Türkiye Petrol, Kimya, Lastik İşçileri Sendikası Petrol-İş Arasında İmzalanan Toplu İş Sözleşmesi 01.01.2005-31.12.2006, m. 34, 35, 36, 37, 38.

${ }^{11}$ Tüpraş Türkiye Petrol Rafinerileri Anonim Şirketi Genel Müdürlüğü ve Bağlı İşyerleri İşletme Toplu İş Sözleşmesi, Basım 22 Ağustos 2011, m. 23.

${ }_{12}$ Bkz. Türkiye Toprak İşverenleri Sendikası İle Çimse-İş Sendikası arasında bağıtlanan Seramik Grubu Toplu İş Sözleşmeleri (01.01.2004 - 31.12.2006); Çimento Müstahsilleri İşverenleri Sendikası ile Türkiye Çimse-İș Sendikası arasında bağıtlanan Çimento Grubu Toplu İş Sözleşmesi (01.01.2004 - 31.12.2005); Türkiye Tekstil Sanayii İşverenleri Sendikası ile Teksif; Türkiye Tekstil 
Daha 4857 sayılı Kanun yürürlüğe girmeden metal işkolunda, MESS grubunda, 2002 yılında bağıtlanan grup toplu sözleşmelerine konulan "uyum maddeleri" ile sözleşmelerin yürürlük süresi içinde İş Kanununda değişiklik yapılması halinde, çalışma süreleri, fazla çalışmalar gibi kritik toplu sözleşme hükümlerinin yerini "herhangi bir tadil protokolüne gerek kalmaksızın" yeni yasa hükümlerinin alacağı hükme bağlandı. Böylece 1475 sayılı Kanun döneminde kabul edilmiş olan ayrintılı düzenlemeler terk edilerek, çalışma süreleri ve fazla çalışmalar konusunda 4857 sayılı İş Kanunu hükümlerinin uygulanacağ 1 kabul edilmiş oldu. ${ }^{13}$ MESS grubunda 01.09.2004-31.08.2006 dönemi grup pazarlığ 1 öncesinde önceki toplu iş sözleşmeleri bu uyum maddelerine göre revize edilerek yeniden imzaland.

Öte yandan seramik grubunda bağıtlanan toplu iş sözleşmelerinde, "denkleştirme çalışmaları hususunda 4857 sayılı İş Kanunundaki usule uyulacağı" açıça hüküm altına alındı. Bu yolla toplu iş sözleşmelerinde görünürde değiştirilmeden kalan işyerlerinde çalışma süresinin haftada 45 ve günde 7,5 saat olduğuna ilişkin düzenlemesinin, yoğunlaştırılmış iş haftası uygulamasını

Örme ve Giyim Sanayii İşçileri Sendikası (Türk-İş) 55 İşyeri, Tekstil; Tekstil İşçileri Sendikası (DİSK) ve Öziplikİş (Hak-İş) 5 İşyeri Grup Toplu Sözleşmeleri (01.09.2004 01.04.2007); Uşak Tekstil İşverenleri Sendikası (Bağımsız) ile Teksif (Türk-İş) arasında bağıtlanan Grup Toplu Sözleşmesi 6 İşyeri (01.07.2004 - 30.06.2006); Metal Sanayii İşverenleri Sendikası (MESS) ile Türk Metal (Türk-İş) 117 İşyeri, Birleşik Metal (Disk) 27 İşyeri ve Çelik-İş̧ (Hak-İş) 9 İşyeri Grup Toplu İş Sözleşmeleri (01.09.2004 - 31.08.2006). 13 "Ek Geçıcı Madde 2: Grup TíS dönemi içinde İş Kanunu'nda değişiklik yapılması halinde, Grup Toplu İş Sözleşmesi'nin 25, 26, 28, 29, 30, 31, 32, 34. maddeleri (Birleşik Metal-İş-MESS Gr. TİS' de: 26, 28, 29, 30, 31, 35, 47, 48, 51, 52, 61. maddeleri ve Ek Madde 5'in) parasal, süresel ve oransal içerikleri hariç yeni Yasa'nın ilgili hükümleri, herhangi bir tadil protokolüne gerek kalmaksızın Yasa'nın yürürlük tarihi ile eş zamanlı olarak yürürlüğe girer." Türk Metal Sendikası - MESS Grup Toplu İş Sözleşmesi: (2002-2004) 15 Kasım 2002 tarihli Anlaşma Tutanağı'na istinaden 25 Kasım 2002 tarihinde imzalanmıştır.; Birleşik Metal-İş - MESS Grup Toplu İş Sözleşmesi: (2002-2004) 25 Kasım 2002 tarihli Anlaşma Tutanăğ'na istinaden 3 Aralı 2002 tarihinde imzalanmıştır. engelleyici niteliği ortadan kaldırılmış oldu. ${ }^{14}$ Kimi sektörlerde işveren sendikalarının toplu pazarlık stratejilerinin ikinci adımının gerçekleştirildiğine de tanık olduk. Bağıtlanan kimi grup toplu iş sözleşmesinde, çalışma saatlerinin işverence değiştirilebileceği açıkça hüküm altına alındı. Benzer şekilde kimi sözleşmelerde, "günlük çalışma sürelerinin tespiti işverene aittir" hükmü getirildi. Çimento grubunda toplu sözleşmeye "İşveren, 4857 sayılı İş Kanununda yer alan iş sözleşmesi türlerini ve işin düzenlenmesini düzenleyen hükümlerini işyerinde çalışan işçilere hiçbir kayda tabii olmadan uygulayabilir" hükmü kondu. ${ }^{15}$ Denkleştirme çalışmaları ayrıntılı olarak düzenlendi, denkleştirme süresi Kanunda izin verilen en üst sınır olan dört aya kadar genişletildi. ${ }^{16}$ Böylelikle esnek çalışmanın önündeki engeller kaldırıldığ1 gibi, yoğunlaştırılmış iş haftası uygulayabilmesi işverene garanti edildi. Çimento ve tekstil gruplarında telafi çalışmalarını düzenleyen hükümler toplu sözleşmelere alındı. ${ }^{17}$

\footnotetext{
14 "Denkleştirme çalışmaları hususunda 4857 Sayılı İş Kanununun 63.Maddesindeki usule uyulur." ve "Denkleştirme esasının uygulandığı süre içinde, işçinin bir haftalık çalışma süresi 45 saati aşsa dahi fazla çalışma olarak nitelendirilemez. Bu halde denkleştirme dönemi içinde ortalama haftalık çalışma süresi 45 saati aşıyor ise bu aşan kısım fazla çalışmadır." Türkiye Toprak İşverenleri Sendikası ile Çimse-İş Sendikası arasında tek, tek bağıtlanan seramik grubu toplu iş sözleşmeleri, 01.01.2004-31.12.2006, m. 20 ve 22.

15 Türkiye Toprak İşverenleri Sendikası ile Çimse-İş Sendikası arasında tek, tek bağıtlanan seramik grubu toplu iş sözleşmeleri, 01.01.2004-31.12.2006, m. 16.

16 "İşveren haftalık normal çalışma süresini, işyerlerinde haftanın çalışılan günlerine, günde onbir saati aşmamak koşulu ile farklı şekilde dağıtabilir. Bu halde dört aylık süre içinde işçinin haftalık ortalama çalışma süresi, normal haftalık çalışma süresini aşamaz." Çimento Müstahsilleri İşverenleri Sendikası İle Türkiye Çimse-İş Sendikası Arasında Çimento Fabrikaları İle İlgili Olarak Aktedilen Toplu İş Sözleşmesi, 01.01.2004 - 31.12.2005, m. 18/A-a. Düzenleme fazla çalışma maddesiyle de tamamlanmaktadır: "İşşsartları gereği işveren işçilere fazla çalışma yaptırabilir. İş Kanununun 63 üncü madde hükmüne göre denkleştirme esasının uygulandığı hallerde, işçinin haftalık ortalama çalışma süresi, normal haftalık iş süresini aşmamak koşulu ile, bazı haftalarda toplam 45 saati aşsa dahi bu çalışmalar fazla çalışma sayılmaz." Aynı yerde, m. 21.

17 "Zorunlu nedenlerle işin durması, ulusal bayram ve genel tatillerden önce veya sonra işyerinin tatil edilmesi
} 
Buna karşılık, deri işkolunda, yürütülen grup toplu iş sözleşmesi görüşmelerinde esnek çalışmaya ilişkin hükümler uyuşmazlık konuları içinde yer almadı. 4857 sayılı İş Kanununun getirdiği esnek çalışmaya ilişkin kavramlar deri endüstrisinde bağıtlanan grup toplu sözleşmesine girmedi. Yine petrol, kimya sektörlerinde Petrol ve Lastik İşverenleri Sendikası (Kiplas)'la ayrı, ayrı bağıtlanan işyerleri düzeyindeki toplu iş sözleşmelerinde ve lastik sektöründe işveren grubuyla yürütülen grup sözleşmesinde de esnek çalışmaya ilişkin yeni düzenlemelere yer verilmedi. İnceleme konumuzu teşkil eden ve 4857 sayılı İş Kanununun yürürlüğe konulmasının ardından bağıtlanan ilk grup sözleşmesi olan cam grup sözleşmesi de çalışma sürelerinin esnekleştirilmesine ilişkin hükümlere yer vermeyen önemli sözleşmelerinden biri oldu. Cam grup sözleşmesinde 2003 sonrasında da, atipik çalışma modellerini sınırlayan, taşeron uygulamasını yasaklayan düzenlemeler korundu.

\section{Cam sektöründe esnekleşme ve toplu pazarlık}

\section{Cam grup sözleşmesinde esnek istihdam}

veya benzer nedenlerle işyerinde normal çalışma sürelerinin önemli ölçüde altında çalışılması veya tamamen tatil edilmesi ya da işçinin talebi ile kendisine izin verilmesi hallerinde, işveren iki ay içinde çalışılmayan süreler için telafi çalışması yaptırabilir. / Bu çalışmalar fazla çalışma veya fazla sürelerle çalışma sayılmaz. / Telafi çalışmaları, günlük en çok çalışma süresini aşmamak koşulu ile günde üç saatten fazla olamaz. Tatil günlerinde telafi çalışması yaptırılamaz." Çimento Müstahsilleri İşverenleri Sendikası İle Türkiye Çimse-İş Sendikası Arasında Çimento Fabrikaları İle İlgili Olarak Aktedilen Toplu İş Sözleşmesi, 01.01.2004 - 31.12.2005, m. 18/D. Teksif, Türkiye Tekstil Örme Ve Giyim Sanayii İşçileri Sendikası, Türkiye Tekstil Sanayii İşverenleri Sendikası, 20. Dönem Grup Toplu İş Sözleşmesi, 01.09.200401.04.2007, m. 20, DİSK/Tekstil, Tekstil İşçileri Sendikası ile Türkiye Tekstil Sanayii İşverenleri Sendikası Arasındaki 20. Dönem Grup Toplu İş Sözleşmesi, Yürürlük 01.09.200401.04.2007, m. 20, Öziplik-İş Sendikası ile Türkiye Tekstil Sanayii İşverenleri Sendikası, Grup Toplu İş Sözleşmesi, m. 20. Uşak grubunda da aynı düzenlemeler yer almaktadır. Bkz. Teksif, Türkiye Tekstil Örme Ve Giyim Sanayii İşçileri Sendikası, Uşak Tekstil İşverenleri Sendikası, Grup Toplu İş Sözleşmesi, 01.07.200430.06.2006.
Cam grup sözleşmesinin işin düzenlenmesine ilişkin hükümleri 80'lerin ikinci yarısında, özellikle 1989'da şekillendi. 90'ların başlarındaki işçi ve sendika haklarını daha da ileri götürme çabaları kısa zaman sonra yerini "kazanılmış hakların korunması" mücadelesine bıraktı. Cam grup sözleşmesinde henüz 1475 sayılı İş Kanunu yürürlükteyken geliştirilen ve esnekliği önemli ölçüde sınırlayan -bazı çok önemli alanlarda yasaklayan- düzenlemeler de 80'li yılların sert sendika mücadelesinin ürünü olarak bugün de varlığını korumaktadır.

Kristal-İş, 1980 Eylül'ünden sonra yeniden toplu masasına oturduğu 1984 yılı sonlarında, o yıllarda 3 binin üzerinde işçinin çalıştığ Paşabahçe cam fabrikasında çoğu yıllardır geçici statüde çalıştırılan 400'ün üzerinde işçinin kadro talebiyle karşı karşıya kaldı. 1985'te bağıtlanan grup sözleşmesiyle bu işçilerin daimi işçi kadrosuna geçirilmeleri başarıldı. Grup sözleşmesine sürekli işlerde geçici işçi çalıştırılmasını sınırlayan bir hüküm de kondu. Sürekli işlerde 3 aydan fazla belirli süreli iş sözleşmesiyle çalıştırılanların sendikaya üye olmaları kaydıyla toplu iş sözleşmesinin bütün hükümlerinden yararlandırılacakları kabul edildi. ${ }^{18} 1987$ yılında bu 3 aylık süre 1 aya indirildi. ${ }^{19} 1989$ sözleşmesinde bu madde cam işkolunda kesin bir "taşeron yasağı" getiren bir hükümle yeniden düzenlendi: “... Sürekli işlerde, geçici işçi ve müteahhit firma çalıştırılamaz." 20

Fonksiyonel esneklik uygulamalarının sınırlandırılması açısından önemli bir düzenlemeyi Kristal-İş, daha 1985 toplu pazarlık sürecinde geliştirerek toplu sözleşmeye koymayı başardı: "İşçiler, işyerinde, kendi işlerinden tamamen farklı

\footnotetext{
18 Türkiye Cam Çimento ve Toprak Sanayii İşverenleri Sendikası - Çimento Cam Seramik ve Toprak Sanayii İşçileri Sendikası (Kristal Çitser-İş), 10. Dönem Toplu İş Sözleşmesi, 01.01.1985-31.12.1986, m. 20.

19 Türkiye Cam Çimento ve Toprak Sanayii İşverenleri Sendikası - Çimento Cam Seramik ve Toprak Sanayii İşçileri Sendikası (Kristal-İş), 11. Dönem Toplu İş Sözleşmesi, 01.01.1987-31.12.1988, m. 20.

20 Türkiye Cam Çimento ve Toprak Sanayii İşverenleri Sendikası - Çimento Cam Seramik ve Toprak Sanayii İşçileri Sendikası (Kristal-İş), 12. Dönem Toplu İş Sözleşmesi, 01.01.1989-31.12.1990, m. 14.
} 
nitelikteki bir başka işe, yazılı onayları olmaksızın nakledilemezler. Zorunlu ve olağanüstü durumlarda bu hüküm uygulanma. Ancak, bu durumlar ortadan kalktığında işçiler, derhal eski işlerine dönerler."21 1987 yılında bu hüküm "tamamen" ibaresi çıkartılarak daha da sınırlayıcı bir düzenlemeye dönüştürüldü. ${ }^{22}$ Hüküm bugün de yürürlüktedir.

Cam grup sözleşmesinde esnekliğe ilişkin bir düzenleme de "İzin değişim ekibi" olarak adlandırılmak suretiyle hüküm altına alınmıştır. İzin dönüşüm ekibi, toplu iş sözleşmesinin "Yıllık Ücretli İzinler" başlıklı 26. Maddesinin $C$ bendinde düzenlenmiștir. Bentte yıllık ücretli izinlerin, "yılın Nisan ve Ekim ayları arasında" kullandırılacağı kaydedilmekte ve bu dönemde işin aksamaması amacıyla belirli süreli iş sözleşmesiyle işçi çalıştırılabileceği kaydedilmektedir. "İşveren yılın Nisan ve Ekim ayları arasındaki süre ile ve işyerlerinin sendika ile mutabık kalınacak bölümleri ile sınırlı olarak ve bu süre içinde sadece yıllık ücretli izin hakkını kullanan işçilerin çalıştıkları bölümlerde çalıştırılmak üzere 'izin dönüşüm ekibi' adı altında işçi alabilir. Bu işçilere Tís hükümleri uygulanmaz ve bu işçiler Tís gereğince işçi ücretlerine yapılacak artışlar için esas alınan ücret ortalamalarının hesaplanmasında dikkate alınmaz. Bu işçiler sendikaya üye olduklarında ücretlerine \% 30 oranında sendika zammı yapılır." İlk kez, 2001 yllında toplu iş sözleşmesine ${ }^{23}$ giren düzenleme bugün de yürürlüktedir. Uygulamada izin dönüşüm ekibi olarak işe alınan işçilerin önemli bir bölümü dönem sonunda kadroya alınmaktadırlar.

\footnotetext{
${ }^{21}$ Türkiye Cam Çimento ve Toprak Sanayii İşverenleri Sendikası - Çimento Cam Seramik ve Toprak Sanayii İşçileri Sendikası (Kristal Çitser-İş), 10. Dönem Toplu İş Sözleşmesi, 01.01.1985-31.12.1986, m. 15.

${ }^{22}$ Türkiye Cam Çimento ve Toprak Sanayii İşverenleri Sendikası - Çimento Cam Seramik ve Toprak Sanayii İşçileri Sendikası (Kristal-İş), 11. Dönem Toplu İş Sözleşmesi, 01.01.1987-31.12.1988, m. 21.

${ }^{23}$ Çimento Cam Seramik ve Toprak Sanayii İşçileri Sendikası (Kristal-İş) - Türkiye Cam Çimento ve Toprak Sanayii İşverenleri Sendikası, 18. Dönem Toplu İş Sözleşmesi, 01.01.2001-31.12.2002, m. 27.
}

Ve iş/ücret gruplar1... Cam grubunda 1983 yılından bu yana uygulanan iş/ücret grupları, "İş Değerlendirmesi Sistemi" ve bu sistemin esaslı bir parçası olarak uygulamaya giren iş tanımlarına bağlı olarak toplu iş sözleşmesinde yer almaktadır. Bu sistem işleri birbirinden ayırmakta, tanımlamakta ve her işin kapsamını açık ve sınırlayıcı biçimde belirlemektedir. ${ }^{24} \mathrm{Ve}$ ironik biçimde sistem uzun süre, eğitimli, vasıflı işgücüne dayanan ve işin kapsamının/sınırlarının flulaştığı fonksiyonel esnekliği de içeren "Toplam Kalite Yönetimi" ile birlikte işletilmeye çalışılmıştır.

\section{Toplu pazarlık sürecinde Cam İşveren Sendikasının esneklik arayışları}

TISK'in politikalarına paralel olarak Cam İşveren Sendikası da 4857 sayılı kanunun yürürlüğe girmesini izleyen ilk müzakerelerde, cam grubunda 2003 yılında 19. Dönem toplu pazarlık süreci başlarken esneklik konusundaki yaklaşımını/1srarını ortaya koydu. 19. dönem toplu pazarlık süreci, işveren sendikasının Kristal-İş'in işkolu yetkisine itirazı nedeniyle çok önemli bir gecikmeyle 18 Temmuz 2003 günü İstanbul Topkapı'daki şişe fabrikasında ve bir çatışma havasında başlamıştı. Bu ilk oturumda Şişecam adına yapılan konuşmada, bu kez toplu sözleşme masasının bir "imtihan masası" olacağ1 özelikle vurgulanmıştı. Bu, tarafların "ateşle imtihanı" idi: "Eski söylemlerle kalakalıp, çağın dışına mı düşeceğiz, yoksa çağın yeni koşullarının gerektirdiği esnekliği, uyum yeteneğini ve sağduyuyu mu sergileyeceğiz?"25

Ve Cam İşveren Sendikası müzakere sürecinin başlarında, 26.09.2003 tarihinde Kristal-İş'e yazılı bir karşı-teklif verdi. İşveren sendikası

\footnotetext{
24 İlk kez 1983 tarihinde Yüksek Hakem Kurulu (YHK) tarafından 26 Temmuz 1983 gün ve 18116 sayılı Resmi Gazete'de yayımlanarak yürürlüğe konulan cam grup toplu iş sözleşmesinin ekinde 5 ücret grubuna göre düzenlenmiştir. "Ek E- Cam Sanayi İş Grupları Kademe Listesi" ile uygulamaya giren bu sistem, 1985 yilında bağıtlanan toplu iş sözleşmesi ile 10 iş/ücret grubuna göre restore edilmiştir. 2003 yılından sonra iş değerlendirme sistemi bir kez daha revize edilmiş, işler ve dolayısıyla da işçiler 5 iş/ücret grubuna ayrılmıştır.

${ }^{25}$ Cam Kesimi 19. Dönem Toplu İş Sözleşmesi Görüşmeleri Açılış Konuşması, Teoman Yenigün, Cam İşv. Send. Y.K. Başkanı, Topkapı 18.7.2003, Kristal-İş Arşivi.
} 
toplu pazarlık masasına koyduğu bu teklifinde, toplu iş sözleşmesinin çalışma süreleri ve işin düzenlenmesine ilişkin hükümlerinin, yürürlüğe girmiş olan 4857 sayılı İş Kanunu'nun esneklik öngören hükümleriyle uyumunun gerçekleştirilmesini amaçlamaktaydi.

Cam İşveren Sendikası, toplu sözleşmenin sürekli işlerde geçici işçi ve müteahhit (taşeron) firma çalıştırılmasını açık ve kesin bir dille yasaklayan hükmüne karşılık şu yeni düzenlemeyi önermişti: "İşyerinde alt işveren ilişkisinde İş Yasası hükümleri uygulanır. Belirli Süreli İş Sözleşmesi Yasa'da belirtilen hallerde yapılabilir."26

Cam grup sözleşmesindeki günlük ve haftalık çalışma sürelerini açık ve kesin olarak belirten düzenlemeleri de esnetmeyi hedefleyen işveren sendikası, çalışma sürelerinde 4857 sayılı İş Kanunu hükümlerinin uygulanmasını öngören bir öneri verdi. Buna göre, "Haftalık çalışma süresi ve bu sürenin haftanın çalışılan günlerine dağılımı İş Yasası hükümleri dikkate alınarak işverence" belirlenecek ve "Bu halde dört aylık süre içerisinde haftalık ortalama çalışma süresi normal haftalık çalışma süresini" aşamayacaktı. Günlük çalışmanın başlama ve bitiş saatlerinde ve ara dinlenmesi uygulamasında da İş Kanunu hükümleri geçerli olacaktı. Ayrıca "İş Yasasının 64. Maddesinde belirtilen hallerde yasa hükümlerine uygun şekilde telafi çalışması" yapilabilecekti.

İşveren sendikasının karşı-teklifinde bunlardan başka, deneme süresinin 4 aya çıkarılmasını, iş değișikliğinde İș Kanunu hükümlerinin uygulanmasını, genel tatillerde kesintisiz çalışmanın esas olduğunu öngören değişiklikler de yer alıyordu.

Kristal-İş bu önerilerin tamamını kesin ve açık bir dille reddetti. İşveren sendikasının 2003 Ağustos'unda müzakereler sürerken Kristalİş'e gönderdiği bir yazıda bu tutum yerilmekte ve yazıya işveren sendikalarının 4857 sayılı Kanunla getirilen esneklik hükümlerini yetersiz gören yaklaşımı da yansımaktadır.

${ }^{26}$ Orijinal belge, Kristal-İş Arşivi.
“60 yılı aşkın bir süredir uygulanan, 1475 sayılı İş Yasası değiştirilmiş ve 4857 sayılı yeni İş Yasası yürürlüğe girmiştir. Büyük çoğunluğuyla ve ağırlıklı olarak çalışanlar için başta iş güvencesi olmak üzere yeni haklar getiren yasa, Sendikalarla uzlaşma yoluyla işyerlerinin bir nebze de olsa verimliliğini ve rekabet güçlerini artırabilecek bazı uygulamaları hayatiyete geçirme imkânı da tanımıştır. Yasanın getirdiği bu sınırlı imkânlardan yeni dönemde işyerlerinin bir ölçüde de olsa yararlanabilmeleri için Cam İşveren Sendikası'nın getirdiği değişiklik önerileri Sendikanızca katı bir tutum sergilenerek kabul edilmemiştir. İşletmelerin verimliliğini artırarak önce varlığını koruyup sonra devamlılı̆̆ını sağlamaya yönelik bu önerilerin kabul edilmemesinin, 'işyerlerini sevme ve yaşatma' mantı̆̆ıyla ne derece bağdaştığını anlamak mümkün olmamışır." 27

Müzakere sürecinde işveren sendikası, ilk geri adımı 26.09.2003 tarihinde verdiği teklif paketinde attı ve denkleştirme çalışması uygulamasını sendikanın mutabakatına bağlayan bir değişiklik önerdi. Kristal-İş toplu iş sözleşmesinin düzenleyici hükümlerinin tartışmaya açı olmadığını belirterek bu yeni yaklaşımı da reddetti. Uzlaşma sağlanamayınca Kristal-İş cam grup pazarlığı kapsamındaki işyerlerinin tümü için grev kararı aldı ve grevin işyerlerinin tamamında 9 Aralık 2003 günü başlatılacağını ilan etti. Grev, başlayacağı tarihten bir gün önce Bakanlar Kurulu kararıyla 60 gün süreyle ertelendi.. ${ }^{28}$ Kristal-İş'in iptal başvurusu üzerine Danıştay 12 Ocak 2004 günü yürütmenin durdurulmasına karar verdi ve Kristal-İş, işyerlerinin tamamında 30 Ocak günü greve çıtı. ${ }^{29} \mathrm{Ne}$ var ki Bakanlar Kurulu 14 Şubat

27 Cam İşverenleri Sendikası'nın Kristal-İs Sendikası Yönetim Kurulu Başkanlığı'na hitaben, 18.08.2003 tarih ve 2003/171 sayılı yazısı.

28 Bakanlar Kurulu, 04.12.2003 gün ve 2003/6479 sayılı karar, Resmi Gazete, 08.12.2003 gün ve 25281 Mükerrer sayıl..

29 Danıştay 10. Dairesi, 12.01.2004 gün ve E.2003/6134 sayılı kararı. "Danıştay anılan kararında konunun esasına da girerek, "yasal bir grevin yasada öngörülen anlamda milli güvenliği bozucu nitelikte görülebilmesi için, ülke ve devletin özel savunma ve güvenlik altına alınmasını zorunlu kılacak ciddi tehlikelerin ortaya çıkması gerekmektedir" diyerek yasada öngörülen anlamda milli güvenliği bozucu nitelikte olmadığı sonucuna da varmıştır. Başbakanlığın, yürütmenin durdurulması 
2004 günü grevi bu kez "genel sağlı̆̆1 ve milli güvenliği bozucu" nitelikte olduğu gerekçesiyle bir kez daha erteleyecekti. ${ }^{30}$

Çok sert geçen müzakere dönemi sonunda 19. Dönem cam grup sözleşmesi önemli bir gecikmeyle 14 Mart 2004 Pazar günü İş Kule3'te imzalandığında işveren sendikasının esneklik önerilerinin hiç biri toplu sözleşme metnine alınmamıştı.

Cam grup sözleşmesinin imzalanmasından sonra Cam İşveren Sendikası/Şişecam Topluluğu, yeni bir toplu pazarlık anlayışını Şişecam'ın Türkiye'ye yatırım yapmasının bir şartı olarak ortaya koydu. Kristal-İş başkanı, 2004 yılı Temmuz'unda hazırlık çalışmaları sürdürülen yeni cam ambalaj yatırımının Türkiye'ye yapılmasının sendika için öncelikli bir konu olduğunu cam işverenine yazıyla bildirdi. Bu çerçevede, bu işyerinde endüstri ilişkilerinin ve toplu iş sözleşmesi politikalarının yeni bir anlayışla ele alınması; yeni işletmenin rekabet gücünü sağlayacak bir ücret politikası ile idari düzenlemelerin sağlanması hususunda hemfikir olduğunu ve bu konuda gereken çabayı harcayacağını belirtti.

“Esas olan yeni cam ambalaj yatırımının ülkemizde yapılması; ülke ekonomisine ve istihdama katkıda bulunmasıdır. $\mathrm{Bu}$ hepimizin omuzlarındaki sorumluluktur. Bu noktada kimsenin kısa vadeli düşünmeye hakkı yoktur. Kristal-İş Sendikası böylesi bir yükün altına cesaretle girmeye hazırdır." ${ }^{31}$

Kristal-İş Genel Kurulunun ve gerçekleşen yönetim değişikliğinin ardından Kristal-İş'in yeni başkanı, sadece kurumun devamlılığı açısından değil, ama sendikanın ilke ve hedeflerini çok iyi yansıtması açısından da bu taahhütlerin arkasında olduğunu cam işverenine yazıyla bildirdi. ${ }^{32} \mathrm{Bu}$ çerçevede yeni

kararına karşı Danıştay İdari Dava Daireleri Genel Kurulu'nda yaptığı itiraz, 12.02.2004 günü reddedilmiştir. ${ }^{30}$ Bakanlar Kurulu, 11.02.2004 gün ve 2004/6782 sayılı karar, Resmi Gazete, 14.02.2004 gün ve 25373 sayıll.

${ }^{31}$ Kristal-İş Genel Başkanı Mustafa Bağçeci imzalı, Cam İşverenleri Sendikası Yönetim Kurulu Başkanı ve Şişecam Cam Ambalaj Grup Başkanı Teoman Yenigün'e hitaben 29 Temmuz 2004 günlü yazı, Kristal-İș arşivi.

32 Kristal-İş Genel Başkanı Bilal Çetintaş imzalı, Cam İşveren Sendikası Yönetim Kurulu Başkanı ve Şişecam kurulacak fabrikalar için protokoller tutuldu ve bu fabrikaların cam grup sözleşmesine dâhil edilmeleri altı yıllık bir geçiş sürecine bağlandı.

Kristal-İş Şişecam'la bu protokollerle bağlı olarak Bursa'da kurulan iki fabrikada toplu sözleşmeler imzaladı. Bu müzakerelerde de Şişecam, 4857 sayılı İş Kanunu'nun esnek çalışma hükümlerinin bu fabrikaların toplu iş sözleşmelerine alınmaları konusundaki ısrarını/yaklaşımını bir kez daha ortaya koydu, Kristal-İş'e bir toplu sözleşme teklifi verdi. Cam grup sözleşmesinde taşeron ve geçici işçiyi yasaklayan düzenleme Şişecam'ın teklifinde yer almamaktaydı. Teklifte ayrica, çalışma sürelerine ilişkin olarak yoğunlaştırılmış iş haftası uygulamasına imkân tanınmaktaydı. Şişecam teklifinde 4857 sayılı İş Kanunu ile getirilen esnek çalışma modellerinin hemen tamamı yer almaktaydı:

"İşçilerin [sendikanın değil] onayı ile gerektiğinde haftalık normal çalışma süresi, haftanın çalışılan günlerine, günde fazla çalışmalar da dâhil 11 saati aşmamak koşulu ile farklı şekilde dağıtılabilir. Bu halde en fazla 4 ay olmak üzere önceden belirlenerek ilan edilecek süre içinde iş̧̧inin haftalık çalışma süresi, normal haftalık çalışma süresini aşamaz."

“İşin ve işyerinin gerektirdiği hallerde işveren İş Yasasının 64. Maddesi hükümlerine uygun olarak Telafi Çalışması yaptırabilir."

“İşveren, genel ekonomik kriz veya zorlayı1 sebeplerin vukuunda İş Yasasının 65. Maddesi hükmü gereğince kısa çalışma yaptırabilir veya işyerinde faaliyeti geçici süreyle kısmen veya tamamen durdurabilir."

“İş Kanununun 63. Madde hükmüne göre denkleştirme esasının uygulandığı hallerde, üyelerin haftalık çalışma süreleri normal haftalık iş sürelerini aşmamak koşulu ile bazı haftalarda toplam 45 saati aşsa dahi bu çalışmalar fazla çalışma sayılmaz." ${ }^{33}$

Bağıtlanan ilk sözleşmede bu önerilerin hepsi sendika tarafından geri çevrildi ve bu maddelerle ilgili olarak cam grup sözleşmesi hükümleri kabul edildi. Ancak cam grup

Cam Ambalaj Grup Başkanı Teoman Yenigün'e hitaben, Kristal-İş arşivi.

${ }^{33}$ Kristal-İş arşivi. 
sözleşmesindeki sürekli işlerde müteahhit (taşeron) firma ve geçici işçi çalıştırılmasını yasaklayan hüküm bu sözleşmelere alınmadı. Bu fabrikalardan altı yıllık geçiş süresini 2011 yılı sonunda tamamlayan Anadolu Cam Yenişehir Sanayii A.Ş. 2012-2013 yıllarını kapsayan 23. Dönemde cam grup sözleşmesine dâhil oldu.

\section{Cam sektöründe toplu sözleşmeye rağmen esneklik uygulamaları}

Cam grup sözleşmesindeki düzenlenen "kapsamdışı personel" ve "izin dönüşüm ekibi" yanında, 80'lerin sonlarından bu yana varlığını sürdüren taşeronlaşma ve son dönemde ortaya çıkan kursiyer ${ }^{34}$ çalıştırılması sektörde yıllar içinde istihdamın yapısını köklü biçimde etkilemiş, işgücü profilini dikkat çekici biçimde değiştirmiş ve önemli bir işçi kitlesi bu yolla toplu pazarlık sürecinin kapsamı dışına çıkarılmıştır.

Cam grubunda 90'larla birlikte grup sözleşmesi yürütülen diğer sektör gruplarında olduğu gibi -metal grubu istisna tutulmalıdırbir çözülme, gerileme dönemine girilmiştir. Cam grubunda 60'lardan başlayarak Türkiye Cam Çimento ve Toprak Sanayii İşverenleri Sendikası (Cam İşveren) kapsamında yer alan irili ufaklı işyerleri işveren sendikasının ve toplu pazarlık sürecinin kapsamı dışına kaçmış, 1993 yılından sonra da grup Şişecam Topluluğu işyerleriyle sınırlanmıştır. Cam grubunda 1989 yilinda 11847 olan toplu pazarlık kapsamındaki işçi sayısı 2012 yılında 4971'e gerilemiştir. Cam grubunun Şişecam Topluluğu şirketleriyle sinırlandığı 1993 yılından yeni İş Kanunu'nun yürürlüğe girdiği ve grupta da İş Değerlendirme Sisteminin revize edilerek 10’lu sistemin terkedildiği 2003

\footnotetext{
34 Kursiyerler, İşkur tarafından oluşturulan "İstihdam Garantili İşgücü Yetiştirme Kursları" kanalıyla ve günlük ödemeleri de kurumca karşılanmak suretiyle işyerlerinde çalıştırılmaktadır. Kurs süresince gene Kurumca iş kazası ve meslek hastalığına karşı sigortalanmaktadır. Bunun yanında, kursiyerler, işyerlerinin servis ve öğle yemeğinden istifade edebilmektedir. Kursiyerler, işyerinin kurs düzenlenen mesleğe ilişkin üretimde kullandığı makine pakından yararlanarak işbaşında eğitim ve kurs sonunda düzenlenen sınavda başarı göstermesi durumunda da 'Kurs Bitirme Sertifikası' almaktadır. İşverenlerden taahhütte bulunmaları istenen istihdam oranı en az \% 50'dir.
}

yılına kadar olan dönemde ise toplu pazarlık kapsamındaki işçi sayısı 9197'den 4623'e düşmüştür. $\mathrm{Bu}$ yüzde 50'nin üzerinde bir erimeyi göstermektedir.

$\mathrm{Bu}$ erimenin iş/ücret grupları açısından izlenmesi sendika/toplu pazarlık kapsamındaki işçi sayısındaki gerilemenin bütünüyle vasıfsız işlerde gerçekleşmiş olduğunu ortaya çıkarmaktadır ki bu cam grubunda "esnek istihdam" uygulamalarına ilişkin en temel tespittir. 1993 yllından bu yana vasıfsız (Grup 1-5) ve vasıflı (Grup 6-10) üye sayılarının değişimi Tablo 1'de yer almaktadır. ${ }^{35}$ İlk 5 iş/ücret grubunda çalışan sendikalı işçi sayısı 1993 yılında 5.441 iken bu say1 2003 y1lında 690'a gerilemiştir. Bunun anlamı ilk 5 grupta 10 yıl içinde 4751 sendikalı işçinin işini kaybetmiş olduğudur ki bu sayı neredeyse bugün cam grubu kapsamındaki toplam üye sayısı kadardır. İlk 5 grupta çalışan sendika üyelerinin toplam üye sayısına oranı ise 1993 yılında yüzde 59,1, 2003 yılında ise yüzde $14,9^{\prime}$ dur. Buna karşıllk 6 . ve daha üst gruplarda çalışan sendika üyelerinin sayısında belirtilen tarihler arasında bir azalma olmadığ gibi, kayda değer olmasa da bir artış söz konusudur. Cam grubunda sendika/toplu pazarlık kapsamındaki vasıflı işgücünün toplam işgücüne oranı 1993 yılında 40,9 iken, 2003 yılında yüzde 85,1'dir. 2012 Ocak ayı itibariyle cam grup sözleşmesi kapsamında toplam işçi sayısı 4682 ve değişen gruplama sistemine göre A grubunda (en alt iş/ücret grubu) yer alan işçilerin sayısı 421'dir. Buna göre toplu pazarlık kapsamındaki işçilerin yüzde 91'i üst iş/ücret gruplarında çalışmaktadır. Şişecam Topluluğunun yeni yatırımlarında ise A grubunda çalışan işçi yoktur. Sendika/toplu pazarlık kapsamındaki işçi sayısındaki bu erime iki yolla

\footnotetext{
${ }^{35}$ Listedeki ilk 5 iş/ücret grubunda "vasıfsız" işler, buna karşllık 6 ve daha yüksek iş/ücret gruplarında ise "vasıflı" işler yer almaktadır. 2003 yılından sonra iş değerlendirme sistemi revize edilmiş, işler ve dolayısıyla da işçiler 5 iş/ücret grubuna ayrılmıştır. Bu nedenle gerek sistemin 2003 yılında değişmiş olması nedeniyle ortaya çıkabilecek hatalardan kaçınmak amaciyla ve gerekse taşeronlaşma sürecinin zaten bu ylllar içinde çok büyük ölçüde tamamlanmış olduğu gerçeğinden hareketle kimi karşılaştırmalarda 1993-2003 döneminin esas alınması zorunlu olmuştur.
} 
gerçekleştirilmiştir: Cam grubunda iş unvanlarının birleştirilmesi -iş zenginleştirilmesi- yani "fonksiyonel esneklik" ve taşeronlaşma yani "sayısal esneklik" uygulamaları...

Toplu pazarlık sürecinde iş tanımlarına ilişkin uzun dönemde ortaya çıkan çok önemli bir değişim iş sayısının yıllar içinde sistemli bir biçimde azalmasıdır. İlk kez 1983 yılında YHK tarafindan yürürlüğe konulan cam grup sözleşmesinin ekinde yer alan "Ek E - Cam Sanayii İş Grupları Kademe Listesi" kapsamında 897 iş unvanı bulunmaktadır. Buna karşılık taraflar arasında 2003'de imzalanan 19. Dönem grup sözleşmesi ekindeki "Saat Ücretli Personel İş Değerlendirme Ücret Sinıfları (Ek - B)" kapsamındaki unvan sayısı 54'tür ve 2003 yılından bu yana unvan sayısında bir değişme olmamıştır. Son olarak 3 Eylül 2012'de imzalanan 23. Dönem cam grup sözleşmesinde de unvan sayısı 54'tür. ${ }^{36}$ Yani süreç içinde 843 iş teknolojik nedenler ya da işlerin birleştirilmesi yoluyla ortadan kaldırılmıştır.

"Farklı iş unvanlarının birleştirilerek daha yüksek iş/ücret grubuna yükseltilmesi bir yandan yapılan işleri daha karmaşık hale getirirken vasıfsız işlerin de miktar ve oran olarak azalmasına neden olmuştur." ${ }^{37}$ İş unvanlarının birleştirilmesi, cam sektöründe toplu pazarlık yoluyla yıllar içinde geliştirilen fonksiyonel esnekliğin damgasını vurduğu yeni bir çalışma düzeni ortaya çıkarmıştır. Bu işçi sayısının da yıllar içinde azalmasındaki önemli faktörlerden biri olmuştur. Sendika iş sayısının azalmasının -işlerin birleştirilmesinin- sektörde istihdamı ve dolayısıyla kendi üye sayısını azaltıcı etkisini derhal fark etmiş, karşı çıkmış, ancak buna direnememiştir.

Cam grubunda işgücünün profili açısından önemli bir değişim de işçilerin eğitim düzeyinde gerçekleşmiştir. Bu tespit 80 'lerden

36 Uzun bir zaman aralığı içinde izlendiğinde cam grubunda unvan sayısı 1985 yilında 441, 1995 yılında 436, 2000 y1linda ise $198^{\prime}$ dir.

${ }_{37}$ Şafak, Can (Taşeron (Alt İşveren) Uygulamaları Ve Bir Mücadele Aracı Olarak Sendika Politikaları: Türkiye'de Cam Sektörü Örneği, Tes-Işs, Türkiye Enerji Su ve Gaz İşçileri Sendikası, Mayıs 2008, s. 132. bu yana, sadece cam grubunda değil, özel sektörde toplu sözleşme kapsamındaki sendikalı işçilerin tamamı için de geçerlidir. Türkiye İşveren Sendikaları Konfederasyonu (TİSK), üyesi işveren sendikaları aracılığıyla üye işverenlere uyguladığı anket verilerine göre 2010 yılında işçiler arasında lise, yüksekokul ve üzeri eğitim düzeyine sahip olanlar toplam işçi sayısının yüzde 67,4'üdür. İşçilerin yüzde 20,4'ü ilkokul yüzde 11,9'u ortaokul mezunudur. Sadece okur-yazar olanların ya da okuma yazma bilmeyenlerin oranı ihmal edilebilecek kadar azdır. İmalat sanayiinde lise ve üzeri eğitim düzeyine sahip olanların oranı daha da yüksektir. Bu oranın en yüksek olduğu sektör yüzde 86,6 oranı ile cam sektörüdür. ${ }^{38}$

Cam grubunda 1985 ve 2011 yılları arasında işçilerin eğitim düzeyindeki değişim aşağıdaki tablolarda verilmektedir..

\footnotetext{
38 İmalat sanayiinde 1985-2010 döneminde TISK kapsamında, işkollarında ve ayrıca imalat sanayiinde (ağaç, cam, çimento, deri, gıda, kâğıt, kimya, metal, şeker, tekstil, toprak sektörlerinde) işçilerin eğitim düzeyleri, Bkz. TİSK Çalışma İstatistikleri ve İşgücü Maliyeti verileri.
} 
Tablo 1- Işs/Ücret Gruplarına Göre Cam Grubu İşçi Sayıları (1993-2003)

\begin{tabular}{|c|c|c|c|}
\hline \multirow{2}{*}{ YILLAR } & \multicolumn{3}{|c|}{ İşÇi SAYILARI } \\
\cline { 2 - 4 } & Grup 1-5 & Grup 6-10 & Toplam \\
\hline 1993 & 5441 & 3756 & 9197 \\
\hline 1996 & 3061 & 3007 & 3368 \\
\hline 1998 & 2588 & 4260 & 6848 \\
\hline 2000 & 1382 & 4393 & 5775 \\
\hline 2003 & 690 & 3933 & 4623 \\
\hline
\end{tabular}

Tablo 2 - Cam grubunda eğitim düzeyi (1985-2010)

\begin{tabular}{ccccccc}
\hline & & & & & Yüksek & \\
Yillar & Okur-Yazar & İlkokul & Ortaokul & Lise & Öğrenim & Toplam \\
\hline 1985 & 2,1 & 76,2 & 10,9 & 10,1 & 0,7 & 100,0 \\
1990 & 0,9 & 64,9 & 13,3 & 20,3 & 0,6 & 100,0 \\
1995 & 0,3 & 50,6 & 13,1 & 33,8 & 2,2 & 100,0 \\
2000 & 0,0 & 26,9 & 11,9 & 55,1 & 6,1 & 100,0 \\
2005 & 0,0 & 26,9 & 11,9 & 55,1 & 6,1 & 100,0 \\
2010 & 0,1 & 9,2 & 4,1 & 70,9 & 15,7 & 100,0 \\
\hline
\end{tabular}

Tablo 3 - 2011 yılında cam grubunda eğitim düzeyi.

\begin{tabular}{cccccccc}
\hline 2011 & İlkokul & Ortaokul & Lise & Meslek Lisesi & Ön lisans & Lisans & Toplam \\
\hline Say1 & 358 & 200 & 732 & 2830 & 823 & 28 & 4971 \\
$\%$ & 7,2 & 4,0 & 14,7 & 56,9 & 16,6 & 0,6 & 100,0 \\
\hline
\end{tabular}

Toplu pazarlık kapsamındaki cam işçisi yıllar içinde "çekirdek işgücü" ne dönüşmüştür. Vasıflı, eğitimli, iş güvencesine, görece yüksek ücret düzeyine sahip bir işgücü profili ortaya çıkmıştır.

\section{Taşeron meselesi ve toplu pazarlık}

Vasıfsız işgücünün olağanüstü biçimde gerilemesinin -toplu sözleşme kapsamındaki işçi profilindeki değişmenin- önemli bir nedeni de cam grubunda zaman içinde yaratılan "sayısal esneklik" yani taşeronlaşmadır. "Taşeronlaşma, cam grubunda öncelikle vasıfsız işlerde ortaya çıkmıştır ki bunlar alt iş/ücret grubundaki temizlik, yüklemeboşaltma, meydan, yeniden ayırma, yemekhane, güvenlik, ulaştırma gibi işlerdir.
Sayısal esneklik ve sendikalı işçi sayısındaki erime bir taraftan kimi işlerin işyerleri dışına taşınması diğer taraftan da işyerlerinin kimi bölümlerinin taşeron firmalara verilmesi yoluyla gerçekleştirilmiştir. Nispeten daha geç dönemlerde taşeronlaşmanın kimi üst iş/ücret grubundaki vasıflı ancak "yardımcı" işleri de kapsayacak şekilde yaygınlaşmaya başladığına tanık oluyoruz. Bunlar, bakım ve tamir ustalarının işleri ile elektrik, kaynak gibi işlerdir." 39

Cam grubunda daha 1989 yılında toplu iş sözleşmesine konan açık ve kesin yasaklamaya karşı gene aynı yıllardan başlayarak uygulanagelen en önemli esneklik

\footnotetext{
39 Şafak, Can (2008), ss. 132-133.
} 
taşeronlaşmadır. Kristal-İş en temel mesele olarak gördüğü taşeronlaşmaya yılarca çözüm aramıştır. Önceleri çatışmacı bir yaklaşımla meselenin üzerine giden sendika, 90'ların sonlarına doğru farklı arayışlara yönelmiştir.

17. Dönem cam grup pazarlığ1 öncesinde taşeron meselesi, yeni bir bakış açısıyla 20-21 Aralık 1997 tarihlerinde Kuşadası'nda ve daha sonra 28-29 Kasım 1998 tarihlerinde Mersin'de toplanan Genel Temsilciler Meclisinin gündemine alındı. Sendika, taşeron meselesinin "ücret politikası" ile bağlarını kurmakta ve taşeronlaşmanın ortaya çıktığ1 vasıfsız işlerde farklı bir ücret politikasının uygulanması gereğine işaret etmekteydi: "Halen işyerlerinde taşeron eliyle yürütülen işlerde çalışanların sendikaya üye olmaları koşuluyla, genel ücret politikasından farklı olarak ve halen toplu sözleşme kapsamındaki işçiler ayrı tutularak bir ücret politikası uygulanabilir." $40 \mathrm{Bu}$ ünitelerde toplu sözleşme zamlarının belirlenmesinde temel kriter, emsal sektörlerdeki toplu sözleşmeler ve ücret düzeyi olarak benimsendi. Bu süreçte sendika, bu politikanın bir parçası olarak ve vasıflı işgücünü desteklemek amacıyla iş/ücret grupları arasındaki ücret farkının da kontrollü biçimde artırılması gerektiğini kabul etti. Bu politika ilk kez toplu 18. Dönem (2001-2002) cam grup pazarlığı süreci içinde ele alındı ve sendikanın önerisi doğrultusunda grup sözleşmesinin "Ücret Zammı" maddesinde vasıfsız işlerde işe yeni alınacak işçiler için özel bir düzenleme yapıldı: “TíS'nin imzasından sonra 1-5. kademelere yeni işe giren sendikaya üye olan işçilerin zamları kendi saat ücretleri ve işe girdikleri döneme ilişkin ortalama ücret zammı oranı üzerinden hesaplanıp üyeliklerin işverene bildirildiği tarih ile dönem başı arasında geçen her tam ay için $1 / 6$ oranında eksiltilerek uygulanır." 41 Böylece vasıfsız işlerde çalışan sendika üyelerinin ücret düzeyleri/kazanılmış hakları korunacak ama bu işlere yeni alınacak işçilerin ücret düzeyi

\footnotetext{
${ }^{40}$ Kristal-İş Arşivi.

${ }^{41}$ Çimento Cam Seramik ve Toprak Sanayii İşçileri Sendikası (Kristal-İş) - Türkiye Cam Çimento ve Toprak Sanayii İşverenleri Sendikası, 18. Dönem Toplu İş Sözleşmesi, 01.01.2001-31.12.2002, m. 31/D.
}

sinırlanacaktı. Ne var ki bu müdahale, sorunun çözümünde etkili olmadı.

Toplu pazarlık süreci içinde cam grubunda taşeronlaşmaya karşı bir diğer çözüm arayışı, sektörde "İkinci TİS" olarak bilinen; kimi işlerin Şişecam Topluluğu bünyesinde ancak ayrı bir toplu pazarlık birimi içinde organize edilmesi, düzenlenmesi çabasıdır. İkinci Tís arayışı, 19. dönem grup pazarlığı öncesinde geliştirilmiş ve Kristal-İş Sendikası ile Cam İşveren Sendikası arasında seri toplantılar yapılmıştır. $\mathrm{Bu}$ toplantılarda taşeron maliyetleri, iş kapasitesindeki esneklik konuları ele alınmış, tel örgü içindeki ve tel örgü dışındaki taşeron şirketler tarafından yürütülen işlerin -ve bu işlerde çalışan işçilerin- Şişecam Topluluğu bünyesine aktarılmasının şartları tartışılmıştır. 2002 yılı boyunca sürdürülen İkinci Tís müzakerelerinde bir dizi karara varılabilmiş ve bunlardan bir bölümü tutanak altına da alınmıştır. Genel olarak benimsenen prensipler; sürekli işlerdeki taşeron firmalarla olan sözleşmelerin feshedilmesi, bu işlerin cam işkolunda var olan ve Şişecam Topluluğu'na ait bir firma tarafından -o sırada henüz kapanmış olan Cam Kırı̆̆ı Tesisi- yapılması, bu işçilerin sendikaya üye olmaları, bu işçileri haklarının toplu iş sözleşmesi yoluyla belirlenmesidir. Ancak Cam İşveren Sendikası, bu müzakereler sürerken Kristal-İş Sendikası'nın işkolu çoğunluğuna -2002 Temmuz İstatistiklerine- itiraz etmiş, toplu iş sözleşmesinin yürürlük süresinin sona ermesiyle birlikte işyerlerinde sendika temsilciliklerini kapatmış, check-off sistemini kaldırmış ve "işyerlerinde her türlü sendikal faaliyete engel olacağını" 2 Ocak 2003 günü 2003/1 sayılı yazı ile Kristal-İş'e bildirmiştir. ${ }^{42}$ $\mathrm{Bu}$ hasmane tutum taraflar arasında her türlü diyaloğa son vermiş ve kimi önemli adımların atılmış olduğu İkinci Tís görüşmelerinin zemini de böylece ortadan kalkmıştır.

Cam grup pazarlığ1 sürecinin öncesinde başlayan yetki uyuşmazlığı tarafları sert bir çatışma ortamına sürükleyerek aylarca sürecek, 19. Dönem Cam Grup Toplu İşs

\footnotetext{
${ }^{42}$ Kristal-İş Arşivi.
} 
Sözleşmesi yaklaşık 1,5 yıl gecikmeyle imzalanabilecektir.

Cam İşveren Sendikası ile her türlü diyalog yolunun kapanması karşısında taşeron meselesinin çözümü için Kristal-İş'in önünde bir yol daha vardı: Yargıya başvurmak! Sendika 4 Mart 2002 günü İstanbul İş Mahkemesinde tespit ve sataşmanın önlenmesi talebiyle üç dava açarak, toplu iş sözleşmesine aykırı işlem ve faaliyetlerin ihtiyati tedbir yoluyla durdurulmasina karar verilmesini istedi. Sendikanın elinde daha 2000 yılının Haziran ve Temmuz aylarında yerel iş ve asliye hukuk mahkemelerinden alınmıs, işyerlerindeki taşeron şirketlere, bu şirketlerin işçileri olarak çalıştırılan işçilere, bunların çalıştırıldıkları bölümlere ve yaptıkları işlere ilişkin tespitler vardı. Dava dilekçesine eklenen bu belgeler toplu sözleşmenin 14 . maddesine aykırı olarak sürekli işlerde müteahhit firma çalıştırıldığını kanıtlıyordu. Yargilama sonunda taşerona yaptırılan işlerin tamamı için; durumun toplu sözleşmenin 14. maddesine aykırılık teşkil ettiğine hükmedildi. ${ }^{43}$ Mahkeme kararları 2002 yılının Ekim ayında Yargitay tarafından da onanarak kesinleşti. ${ }^{44}$ Sendika bu davaları kazandı, ancak gereğini yapamadı, toplu sözleşmeye aykırılığı kesin olarak belirlenmiş taşeron uygulamasının üzerine gidemedi. ${ }^{45}$

\footnotetext{
43 Toplu iş sözleşmesiyle "sürekli" işlerde taşeron çalıştırılmasının yasaklandığı ve sürekli- süreksiz iş ayrımının o dönem yürürlükte olan 1475 sayılı İş Kanununun 8. maddesinde yapıldığı, buna göre nitelikleri bakımından 30 günden fazla süren işlerin sürekli iş olduğundan hareketle İş Mahkemesi, taşerona yaptırılan işlerin tamamı için; durumun toplu sözleşmenin 14 . maddesine aykırılık teşkil ettiğine ve işverence toplu iş sözleşmesinin ihlal edildiğine hükmetmiştir. "Celb olunan ve mahkemece tespiti yapılan tespit dosyalarında bilirkişilerce saptanan işlerin sırasıyla (tüm açık ve kapalı alanların, saha temizlik hizmetleri, tahmin tahliye işleri, yemek hizmetleri ve bunların hazırlanmasından verilmesi gerekmiştir." T.C. İstanbul 3. İş Mahkemesi'nin 10.07.2002 gün ve E.2002/202, K.2002/1027 sayıll; 10.07 .2002 gün ve 2002/203, K.2002/1028 say1l, 10.07.2002 gün ve 2002/204, K.2002/1029 sayılı kararları.

44 T.C. Yargitay 9. Hukuk Dairesinin 30.10.2002 gün ve E.2002/20282, K.2002/18769 saylli; 30.10 .2002 gün ve E.2002/20283, K.2002/18770 say1li; 30.10 .2002 gün ve E.2002/20284, K.2002/18771 sayıl1 kararlar1.

${ }^{45}$ Bkz. Şafak, Can (2008), ss. 136-137..
}

Cam grubunda 4857 sayılı İş Kanunu'nun getirdiği esnek çalışma biçimlerinin hiç biri grup sözleşmesi metnine girmedi, üstelik belirli süreli iş sözleşmesine ilişkin kontrollü/sınırlı bir model dışında taşeronlaşma kesin bir dille yasakland, iş değişikliği sıkı kurallara bağlandı. Ne var ki bütün bunlar cam fabrikalarında işgücünün parçalanmasını önleyemedi. Tel örgü içinde toplu iş sözleşmesi kapsamındaki sendika üyesi işçilerin -çekirdek işgücünün- yanında kapsamdışı personel statüsündeki ustalar, teknisyenler, büro işçileri; ayrıca taşeron işçileri; izin dönemlerinde belirli süreli iş sözleşmeleriyle çalıştırılan izin ekibi; İşkur kanalıyla zaman zaman üretimde çalıştırılan kursiyerler, önemli bir kitle oluşturmaktadırlar. Tablo $4^{\prime}$ te cam fabrikalarındaki istihdamin yapisı görülmektedir. Bugün cam grubunda toplu iş sözleşmesi kapsamındaki işgücünün toplam işgücüne oranı yüzde 51,7'dir. Tabloya yansımayan ve tel örgü dişına taşeron/yüklenici firmalara- kaçan işler ${ }^{46}$ ve buralarda çalışan işçiler yani "çevre işgücü" de düşünüldüğünde cam işçilerinin yarısının bile toplu sözleşme kapsamında olmadıkları, birbirinden çok farklı statülerle ve çok farklı koşullarla çalıştırıldıkları görülmektedir.

\footnotetext{
${ }^{46}$ Cam ev eşyası üretiminde Trakya Muratlı ve Mersin'de paketleme ve yeniden ayırma işleri, cam ambalaj (şişe/kavanoz) üretiminde Tuzla ve Mersin'de baskı işleri.
} 
Tablo 4 - Cam grup sözleşmesi kapsamındaki işyerlerinde çalışan işçilerin statüsü.

\begin{tabular}{lcccccc}
\hline GRUPLAR & $\begin{array}{c}\text { TİS } \\
\text { KAPSAMI }\end{array}$ & $\begin{array}{c}\text { İİN EKİBं } \\
\text { (Haz. 2012) }\end{array}$ & $\begin{array}{c}\text { KURSIYYR } \\
\text { (Haz. 2012) }\end{array}$ & TAŞERON & $\begin{array}{c}\text { KAPSAMDIŞI } \\
\text { PERSONEL }\end{array}$ & $\begin{array}{c}\text { TOPLAM } \\
\text { İŞÇI }\end{array}$ \\
\hline Cam Ev Eşyası & 1319 & 245 & 70 & 293 & 773 & 2700 \\
Cam Ambalaj & 1460 & 358 & & 330 & 773 & 2921 \\
Düzcam & 1695 & 207 & 140 & 399 & 678 & 3119 \\
Kimyasallar & 497 & 44 & 15 & 76 & 248 & 880 \\
\hline TOPLAM & 4971 & 854 & 225 & 1098 & 2472 & 9620 \\
\hline
\end{tabular}

\section{Son söz}

Toplu pazarlık sendikaların, işçi hak ve özgürlüklerinin korunup geliştirilmesi mücadelesiyle bağlı olarak işin, iş şartlarının düzenlenmesine müdahale edebilecekleri araçların en başında gelmektedir. Kuşku yok ki sendikalar açısından toplu pazarlık sürecinin başarısı konjonktürel ve son derece karmaşık pek çok faktöre bağlıdır.

21. Yüzyıl değişim/dönüşüm, küreselleşme, rekabet, bilgi çağı gibi kavramlarla başladı ve içinden geçtiğimiz dönem solun, emeğin, emek örgütlerinin, işçi sendikalarının hızla gerilediği bir dönem oldu. Türkiye'de de 1980 Eylül'ünün ardından 1989 bahar eylemleriyle, pek çok sektörde birbiri ardına başlatılan kitle grevleriyle, 1991 madenci yürüyüşüyle kısa süren bir yükseliş yaşayan sendika hareketi 90'larla birlikte çözülme sürecine girdi, sendikalaşma oranı, toplu pazarlığın

\section{KAYNAKLAR}

2005 Yılı Kamu Toplu İş Sözleşmeleri Çerçeve Anlaşma Protokolü (04.07.2005)

2007 Yllı Kamu Toplu İş Sözleşmeleri Çerçeve Anlaşma Protokolü (02.07.2007)

2009 Yılı Kamu Toplu İş̧ Sözleşmeleri Çerçeve Anlaşma Protokolü (07.07.2009)

2011 Yılı Kamu Toplu İş Sözleşmeleri Çerçeve Anlaşma Protokolü (19.07.2011)

Bakanlar Kurulu, 11.02.2004 gün ve 2004/6782 sayılı karar, Resmi Gazete, 04.02.2004 gün ve 25373 sayıll.

Birleşik Metal-İş - MESS Grup Toplu İş Sözleşmesi: (2002-2004) 25 Kasım 2002 tarihli Anlaşma Tutanağı'na istinaden 3 Aralık 2002 tarihinde imzalanmıştır. kapsamındaki işçi sayısı her yıl biraz daha azaldi.

Cam grubunda da gerek bu konjonktürün etkileri ve gerekse sendikalı ve gerekse toplu pazarlığın kapsamındaki işçi sayısındaki azalma toplu pazarlik hedeflerine/politikalarına da yansıdı. Toplu pazarlık sürecinde sendika tarafından ortaya konulan iş̧̧i haklarının geliştirilmesi hedefi yerini, "kazanılmış hakların korunması" çabasına bıraktı. Kristal-İş toplu iş sözleşmesinde ağırlıklı olarak 1989, 1991 dönemlerinde kazandığı hakları toplu sözleşme metni üzerinde korumayı başardı ama uygulamada esnekleşmenin, işgücünün parçalanmasının, çok büyük bir işçi kitlesinin ylllar içinde sistemli olarak sendika ve toplu pazarlık kapsamı dışına çıarılmasının önüne geçemedi.

Çimento Müstahsilleri İşverenleri Sendikası İle Türkiye Çimse-İş Sendikası Arasında Çimento Fabrikaları İle İlgili Olarak Aktedilen Toplu İş Sözleşmesi, 01.01.2004 - 31.12.2005.

Danıştay 10. Dairesi, 12.01.2004 gün ve E.2003/6134 sayılı kararı.

DİSK/Tekstil, Tekstil İşçileri Sendikası ile Türkiye Tekstil Sanayii İşverenleri Sendikası Arasındaki 20. Dönem Grup Toplu İş Sözleşmesi, Yürürlük 01.09.2004-01.04.2007.

ETI Maden İşletmeleri Genel Müdürlüğü ve Elektrik Üretim Anonim Şirketi Genel Müdürlüğü Afşin-Elbistan Linyitleri İşletme Müdürlüğü Toplu İş Sözleşmesi, 1.1.2011-31.12.2012.

Genel Maden-İş'in Kamu-İş, Türkiye Taşkömürü Kurumu (TTK) 24. Dönem Toplu İş Sözleşmesi, 1.1.2011-31.12.2012. 
Genel Maden-İş'in Kamu-İş, Maden Tetkik Arama (MTA) 14. Dönem Toplu İş Sözleşmesi, 1.1.2011-31.12.2012.

Kamu İşletmeleri İşverenleri Sendikası (Kamuİş) ile Türkiye Maden İşçileri Sendikası arasında bağıtlanan Türkiye Kömür İşletmeleri Kurumu, 13. Dönem işletme toplu iş sözleşmesi, 1.1.201131.12.2012

Kamu İşletmeleri İşverenleri Sendikası (Kamuİş) ile Türkiye Maden İşçileri Sendikası arasında bağıtlanan Türkiye Kömür İşletmeleri Kurumu 13. Dönem işletme toplu iş sözleşmesi, 1.1.201131.12.2012.

Kristal-İş Sendikası arşivi.

Öziplik-İş Sendikası ile Türkiye Tekstil Sanayii İşverenleri Sendikası, Grup Toplu İş Sözleşmesi, m. 20. Uşak grubunda da aynı düzenlemeler yer almaktadır.

Petkim Petrokimya Holding A.Ş. Genel Müdürlüğü ve Bağlı İşyerleri İçin Kamu İşletmeleri İşverenleri Sendikası Kamu-İş ile Türkiye Petrol, Kimya, Lastik İşçileri Sendikası Petrol-İş Arasında İmzalanan Toplu İş Sözleşmesi 01.01.200531.12.2006.

Petkim Petrokimya Holding A.Ş. Genel Müdürlüğü ve Bağlı İşyerleri İçin Türkiye Kimya, Petrol, Lastik ve Plastik Sanayii İşverenleri Sendikası Kiplas ile Türkiye Petrol, Kimya, Lastik İşçileri Sendikası Petrol-İş Arasında İmzalanan Toplu İş Sözleşmesi 01.01.2011-31.12.2012.

Teksif, Türkiye Tekstil Örme Ve Giyim Sanayii İşçileri Sendikası, Türkiye Tekstil Sanayii İşverenleri Sendikası, 20. Dönem Grup Toplu İş Sözleşmesi, 01.09.2004-01.04.2007,

Teksif, Türkiye Tekstil Örme Ve Giyim Sanayii İşçileri Sendikası, Uşak Tekstil İşverenleri Sendikası, Grup Toplu İş Sözleşmesi, 01.07.2004-30.06.2006.

Tüpraş Türkiye Petrol Rafinerileri Anonim Şirketi Genel Müdürlügü ve Bağlı İşyerleri İşletme Toplu İş Sözleşmesi, Basım 22 Ağustos 2011.

Türk Metal Sendikası - MESS Grup Toplu İş Sözleşmesi: (2002-2004) 15 Kasım 2002 tarihli
Anlaşma Tutanağı'na istinaden 25 Kasım 2002 tarihinde imzalanmıştır.

Türkiye Cam Çimento ve Toprak Sanayii İşverenleri Sendikası - Çimento Cam Seramik ve Toprak Sanayii İşçileri Sendikası (Kristal Çitser-İş), 10. Dönem Toplu İş Sözleşmesi, 01.01.198531.12.1986. Kristal-İş, 2821 sayılı Sendikalar Kanunu'nun 1983 tarihinde yayınlanmasıyla birlikte cam işkolunun çimento ve toprak işkoluyla birleşmesi üzerine Kristal-Çitser-İş adını almış ancak daha sonra 4-5 Ekim 1986 tarihlerinde toplanan 9. Genel Kurulu'nda kısa adını yeniden Kristal-İş olarak değiştirmiştir.

Türkiye Cam Çimento ve Toprak Sanayii İşverenleri Sendikası - Çimento Cam Seramik ve Toprak Sanayii İşçileri Sendikası (Kristal-İş), 11. Dönem Toplu İş Sözleşmesi, 01.01.1987-31.12.1988.

Türkiye Cam Çimento ve Toprak Sanayii İşverenleri Sendikası - Çimento Cam Seramik ve Toprak Sanayii İşçileri Sendikası (Kristal-İş), 12. Dönem Toplu İş Sözleşmesi, 01.01.1989-31.12.1990.

Çimento Cam Seramik ve Toprak Sanayii İşçileri Sendikası (Kristal-İş) - Türkiye Cam Çimento ve Toprak Sanayii İşverenleri Sendikası, 18. Dönem Toplu İş Sözleşmesi, 01.01.2001-31.12.2002.

Türkiye Toprak İşverenleri Sendikası ile Çimseİş Sendikası arasında tek, tek bağıtlanan seramik grubu toplu iş sözleşmeleri, 01.01.2004-31.12.2006.

Türkiye Toprak İşverenleri Sendikası ile Çimseİş Sendikası arasında tek, tek bağıtlanan seramik grubu toplu iş sözleşmeleri, 01.01.2004-31.12.2006.

Şafak, Can (Taşeron (Alt İşveren) Uygulamaları Ve Bir Mücadele Aracı Olarak Sendika Politikaları: Türkiye'de Cam Sektörü Örneği, Tes-İs,, Türkiye Enerji Su ve Gaz İşçileri Sendikası, Mayıs 2008, s. 132.

Yüksek Hakem Kurulu (YHK) tarafından 26 Temmuz 1983 gün ve 18116 sayılı Resmi Gazete'de yayımlanarak yürürlüğe konulan Cam Grup Toplu İş Sözleşmesi, 01.01.1983-31.12.1984. 